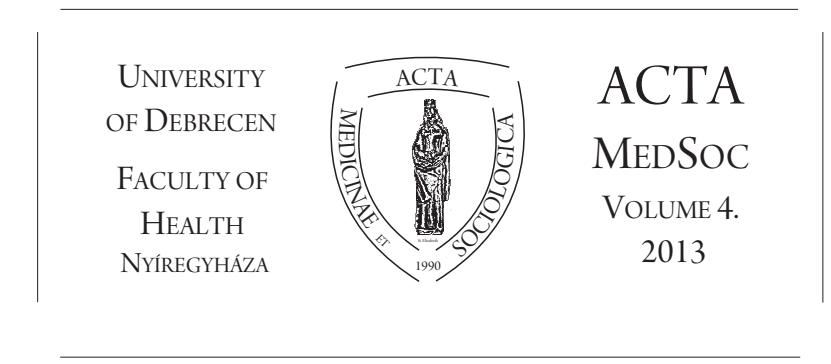

\title{
Közösségi gazdaságfejlesztés a gyakorlatban
}

\section{Mészáros Zsuzsa}

Közösségfejlesztők Egyesülete

DOI: $10.19055 / \mathrm{ams} .2013 .4 / 8-9 / 8$

„Tedd azt, amiben hiszel, és higgy abban, amit teszel!

Minden más csak erô- és idôpocsékolás". Maharaj Nisargadatta

A helyi, közösségi gazdaságfejlesztés lehetôségén egyre többen kezdenek el gondolkodni: társadalomtudósok, közgazdászok, polgármesterek, civilek, helyi lakosok. A megváltozott gazdasági és társadalmi környezet negatív hatásai begyưrúztek a mindennapokba. A tarthatatlan helyzetre elsôsorban nem a statisztikák figyelmeztetnek, hanem a környezetünkben élő emberek a látató gondjaikkal, az egyre terjedő bizalmatlanság, a jövoobe vetett hit hiánya.

A valódi, elkötelezett, alulról építkezố kezdeményezésekre egyre többen figyelnek fel és próbálkoznak hasonló megoldásokkal. Az együttélés sokszínúségében rejlő erô felismerése egyre több településnek, közösségnek nyújt új perspektívát.

Lemásolni pontosan, úgy ahogy egy helyen már megtörtént - nem lehet. A helyi adottságokat, az ott élő emberek közötti viszonyokat nem lehet figyelmen kívül hagyni. A közösségi gazdaságfejlesztés másképp nem múködik, mint azok részvételével, akiket érint.

„Csak a széleskörú és különféle kérdésekben történô részvétel biztosítása esetén lehetséges olyan közjó elérése, amely hưen tükrözi nagyszámú önérdek -maximalizáló egyén sokféle érdekeit." 1

\footnotetext{
${ }^{1}$ Sabine U. O'Hara: A társadalmi sokféleség tisztelete. Megjelent::ValuingSocio-diversity, International Journal of SocialExonomics, Vol. 22. No. 5, 1995. 31-49. Bumberák Mária fordítása
} 
Számos szakirodalom (tanulmányok, cikkek, könyvek) áll rendelkezésre ahhoz, hogy aki új/alternatív gazdasági megközelítésekrôl gondolkodik, az kellőképpen tájékozódni tudjon. A jó példák gyarapodnak, és meg isjelennek 1-1 kiadványban, konferencián és a témában szervezett work shopokon. A kutatások fókuszába egyre inkább a múködés kerül. Mitől múködik, milyen feltételek szükségesek ahhoz, hogy múködjön a helyi gazdaságfejlesztés egyes helyeken, míg másokon nem, vagy alig?

A gazdasági válság elhúzódása, a szegénység egyre nagyobb elterjedése a központi kormányzatot arra ösztönzi, hogy olyan törvényeket, intézkedéseket hozzon, amely áttereli a felelősséget az emberekre, az önfenntartás, öngondoskodás hangsúlyozásával. A feltételek (törvényi, rendeleti, szociálpolitikai) eszközeinek előállítása azonban nem bizonyul elégségesnek, sőt időnként gátjává is válik a szabadon áramló gondolatoknak és kezdeményezéseknek.

A kutatók, és maguk a helyi gazdaság fellendítésén dolgozók az alapelvekben megegyeznek. Fô fogalmaik: lokalitás, belsô erôforrások feltárására, használata, képessé tétel, a hagyományok, a belsô forgalom (termelés-fogyasztás) és a helyi társadalom felkészültsége. Ezek azonban nem mindenhol állnak rendelkezésre.

Fontos kérdés, hogy ki rendelkezik a tulajdonjogokkal, ki rendelkezik az eróforrások feletti döntés jogával.

Lehet, hogy az adott helyen felismert eróforrások vannak (legyen az az emberekben, a természetben, a földrajzi elhelyezkedésben, az infrastruktúrában) azonban a helyi közösség efölött nem rendelkezik. Mások és máshol hozzák meg a döntéseket. Például a település körül magántulajdonban lévô földek vannak, amely fölött, azaz felhasználásáról, a helyi közösség nem tud dönteni.

A másik probléma abból adódhat, hogy rendelkezésre áll ugyan az erőforrás, munkaerőben, infrastruktúrában, környezetben, de annyira leamortizálódott, hogy jelen állapotában nem tud a helyi gazdasági fejlődés alapja és különösen nem, motorja lenni. A fizetőképesség romlik az elszegényedés miatt.Ördögi kör.

\section{A megújulás képességének fontossága}

Azokat a térségeket, amelyeket erőforrás hiányos térségekként jellemeznek és ezt a fizikai környezet állapotában mérik (távolság a centrumtól, leromlott infrastruktúra), ott a számokkal nem egykönnyen mérhető megújulási képesség hiányát nem veszik kellő mértékben figyelembe. Pedig a kulcs itt keresendő. Mitôl tudna egy hely (térség, település) megújulni, vagy bátorságot venni a megújulásra? Nincs birtokában annak a jövőbe vetett hitnek, a saját képességeinek és eróforrásainak, amely elengedhetetlenül szükséges a helyi gazdaság fejlődéséhez.

A szakemberek és a kutatók hangsúlyozzák abelülrôl fakadó(endogén) fejlesztésszükségességét, a helyben, az érintettek által megszületett döntések szükségességét. Dönteni afölött lehet, ami a birtokunkban van. Ezek között vannak olyan dolgok, amelyek egyszerúen felismerhetók. A földról, erdôról, épületekrôl, eszközökről van egy hivatalos dokumentum, amely bemutatja, ki a tulajdonos.Ez lehet egyén, lehet közösség, önkormányzat, állam. A legegyszerúbb az egyén, akinek egyszemélyes 
elhatározásán múlik, hogy mit tesz a tulajdonával. A közösségi tulajdon (pl: erdôbirtokosság) feletti döntés már nehezebb, de a közvetlen részvétel lehetôségét biztosítja. Az önkormányzati és még inkább az állami tulajdon feletti rendelkezés közvetett, képviselők útján történik. Minél nagyobb egységrôl beszélünk, annál inkább egyenes arányban nô a távolság az egyén kompetencia állapota (magáról elhitt kompetencia szintje) és a döntést valójában meghozók kompetencia állapota között. Itt a hangsúly azon van, hogy az emberek, akik a környezetük előnyeit és súlyát is magukon hordozzák, nem hiszik el, hogy a rájuk vonatkozó döntésekbe beleszólási joguk van és, hogy erre képesek is lennének, ha kelló információval, a véleménycsere fórumaival rendelkeznének. A maguk sorsáról szabadon döntô közösségek vágya és a mai realitás között óriási a távolság.

Ahelyi társadalom állapota nem mutatható be könnyen, mérôszámai elvontak, magyarázatot igényelnek. A társadalmi tôke megfoghatatlan fogalom, szemben a pénzzel, a vagyontárgyakkal, az ingatlanokkal, a státuszszimbólumokkal, amelyek látványosak.

Az egymás közötti bizalomról beszélni abban a környezetben, amelyben döntéshozók egyértelmúen nem bíznak meg a helyiek kompetenciájában - elméleti fejtegetésnek minôsül.

\section{A közösség gazdaságfejlesztési törekvések feltételei}

Azok a kezdeményezések, amelyek kellő nyilvánosságot kapnak és így megismerhetôk, azt sejtetik, hogy lennie kell valaminek, vagy valakinek ahhoz, hogy az adott település sikeres legyen befelé és kifelé is. Akiknél nem múködik, azok könnyen mondják, hogy nekik (a sikereseknek) könnyebb, mert nekik ez és az rendelkezésre áll, ilyen és olyan jó pozíciójuk van, nekünk pedig ez sincs és az sincs.

Mi kell ahhoz, hogy egy település felismerje azt, hogy mi van neki és ezzel mit kell tennie? Hogyan érhető el, hogy képes legyen a megújulásra?

A jó gyakorlatok nagyon széles skálán mozognak. Vannak egész térségre kiterjedó kezdeményezések és vannak egy-egy szervezet által megvalósított tevékenységek. Van olyan, amelyik a lakosság minden rétegét megmozdítja, és van olyan, amelynek a kiterjedtsége korlátozott. Van amelyet egy család indított el (Szeles Attila, Hét, Bioéléskamra), és olyan is, amelyet országos szakmai szervezet irányít (Autonómia Alapítvány, Edelényi és Encsi kistérség, Bridge projekt) és olyan is, amelynek a gazdája az önkormányzat ( Túristvándi, Rozsály).

Keressük meg a feltételeket a jó példákban.

Kezdeményező:

Kezdeményező egyén, közösség vagy intézmény, amelyik felismeri, hogy a helyzet 
tarthatatlan, a problémák sokasodnak, ha így folytatódik tovább, akkor a hanyatlás megállíthatatlan, tenni kell valamit, mert helyettük más nem teszi meg. Befolyással bír a többi emberre, tudása, kapcsolati rendszere, funkciója, korábbi elismert tevékenysége vagy családi kötődése miatt. Megbíznak benne az emberek. Õ maga hisz abban, hogy képes a változást elindítani.

\section{Eróforrások:}

A kezdeményező(k) vagy maga rendelkezik saját erôforrásokkal, vagy felismeri a környezetében fellelhető erőforrásokat és tudja, hogy ezek mobilizálhatók.

\section{Hatalom:}

A kezdeményező(k) kezében, birtokában van, vagy rendelkeznek olyan képességekkel (mások meggyốzése, mások képessé tétele), amelyekkel meg tudják szerezni a hatalmat. Ez a hatalom a döntések meghozatalára vonatkozik.

Úgy tûnik, hogy a kulcs a kezdeményezô kezében van. Feltételezzük, hogy kellô előrelátással és önmaga rászánásával indítja el a folyamatot és birtokában van mindannak a képességnek, amely szükséges ahhoz, hogy valódi megújulás kezdődjön el és az fenntartható módon múködjön.

A legfontosabb egy olyan kiinduló szint elérése a közösségben (lokalitásban), amely lehetôvé teszi a továbblépést. Ez a megújulás képességének megszerzése. Nem elég tehát, ha egy emberben megvan ez, a közösségnek magának kell rendelkezni vele.

Mit jelent a megújulási képesség?

A közösség le tudja gyơzni a berögzött szokásait, ki tud lépni a korábbi keretekből, alkalmazkodni tud az új helyzetekhez, önmagán képes változtatni, rugalmas, szervezett, autonómiával rendelkezik a döntések meghozatalában, a máshol múködő jó dolgokat ismeri, és azokat adaptálni tudja, sokrétú kapcsolati rendszere van, mozgékony, a technológiát, technikát tovább tudja fejleszteni, arányosságra és, egyensúlyra törekszik. A változásért képes erőfeszítést tenni, kitartó és következetes. Elébe megy a külső körülmények okozta változásoknak. Kezelni tudja a kockázatokat. Stratégiai szemléletú, hiteles, jellemes.

Mindegyiket egyenként gyakorolni kell. A megújulás képességének birtoklása a cselekvésben mutatkozik meg és hozzávezető út is a cselekvésen keresztül történik.

Itt tehát a hogyanra a válasz. Cselekvés, amely közben további képességek fejleszthetők, úgymint az együttmúködés, a mások szempontjának figyelembevétele, a körültekintés. Gyakorolható az egyenrangúság, a mindenki számára elfogadható megegyezés, a döntéshozatal. Mindezen képességek fejlődése nem egyszeri ügyek megoldására teszik alkalmassá a közösséget, hanem olyan folyamatok irányítására és végigvitelére, amelyeket összefoglalva helyi gazdaságfejlesztésnek nevezünk. 


\section{A helyi, közösségi gazdaságfejlesztés fogalma}

A fogalom meghatározását sokan megtették már, így csak a fentiek összefoglalására vállalkozhatok.

A helyi gazdaságfejlesztés, amegújulásra képes helyi közösségból vagy által kezdeményezett, a helyi erőforrásokon, azok feletti rendelkezésen nyugvó, azok kiáramlását (a szivárgást) arányosan tartó, a külsố erőforrásokat a belsók erôsítésére bevonzó, a különbözố társadalmi csoportok egyenrangú részvételén alapuló, a közösség jólétének elősegítésére irányuló, az érintett közösség által vezérelt folyamat. A folyamat nem hoz látványos eredményeket, de a tevékenységek sokasodásával, így a munka - nélküliség csökkenésével, a jövedelem megtartásával és növelésével, az elvándorlás csökkenésével, a közösségiség, a szolidaritás és az identitástudat erôsödésével jár.

\section{Megoldások}

Hogyan múködik ez a valóságban? A példák mindig kiragadottak, az adott kontextusban érthetók, máshol ugyanígy meg nem ismételhetôk, de hitet adhatnak abban, hogy múködik, múködhet.

Az országosan is ismert jó gyakorlatok bemutatására nem vállalkozhatok, mivel személyesen azokat a folyamatokat nem ismerem. Az általános elveket mindenhol alkalmazzák, hiszen nem is kerülhettek volna anélkül a különbözó helyi gazdaságfejlesztéssel foglalkozó tanulmányok elemzési körébe.

Az alábbi rövid esettanulmányok egy kistérségben 15 éve folyó közösségfejlesztői munka során létrejött közösségi gazdasági kezdeményezéseket mutatják be.

A 15 évvel ezelőtt történtek nem veszítették el aktualitásukat. Ma sokkal nehezebb, terheltebb gazdasági és társadalmi környezetben hasonló kísérletek zajlanak le. Nem volt bennük semmi különleges. Az történt, amire ott és akkor a közösség vállalkozni tudott, hogy változtasson az életén. Ma már óriási értéknek számít, ha egy közösség képes erre.

Mindegyik a helyi szükségletekre reagált közösségi módon, a maga nemében komplex megközelítéssel, de mégsem terjedt ki a probléma minden szegmensére. Mindegyik az önkormányzattól és az államtól független, állampolgári kezdeményezés, de mindegyik mögöttcivil fejlesztôi támogatás állt és áll. A hely és a tevékenységben érintettek erőforrásaira épül mindhárom. Megjelent bennük a szociális-szolidáris elem, a környezet (beleértve a társadalmat) iránti figyelem és a vállalkozási hajlandóság. Nem tekintem ezeket a kezdeményezéseket a szociális gazdaság témakörébe sorolandónak, bár azokat a kritériumokat is részben teljesítik (munkaerôpiacon hátrányos helyzetúek képessé tétele, foglalkoztatás, non profit múködés, az állam által el nem látott szolgáltatások biztosítás, némi támogatással). Inkább úgy fejezném ki, hogy határesetek a szociális gazdaság és a helyi gazdaság között A még múködô két eset közül a korábbiban (2007) megjelent az állami támogatás a foglalkoztatás 
területén, a késóbb kezdődött folyamat esetén pedig még megjelenhet.

Ezt az elkülönítést nem is tartom fontosnak jelen esetben, hiszen 1998 és 2013 között nagyon nagy változások történtek gazdasági és társadalmi szinten is. Közösségi szempontból hasonlóak a nehézségek, amelyek tovább terhelődtek az elidegenedés mélyülésével, a bizalomvesztéssel. Gazdasági és társadalmi szempontból pedig kritikussá vált a helyzet. Az esettanulmányokban igyekszem azt is bemutatni, hogy ezek a változások mennyiben kívántak meg más megoldásokat.

Az elsô két esetben az időbeli távolság és a külsô fejlesztôként való részvétel ad lehetőséget a tárgyszerúbb bemutatásra, a harmadik, napjainkban zajló és személyes érintettséget sem nélkülözô folyamat azonban sok szubjektív elemet tartalmaz még.

\section{A helyszín bemutatása}

A Felsô-Kiskunság az Alföld északi-nyugati részén, részben a Kiskunsági Nemzeti Park területén fekszik, Budapesttől 60 km-re. Mezőgazdasági terület. A szántóföldi növénytermesztés mellett a dohány és füszerpaprika termesztés is jellemzô. A 9000 fôs Kunszentmiklós körül kisebb települések és tanyabokrok találhatók. A tanyák száma, így a családi gazdaságok száma is drasztikusan lecsökkent a '70-es években. A munkanélküliség a rendszerváltást követően az országos átlag fölé elmelkedett. A nagyobb munkáltatók megszúntek.

A Civil Kollégium Alapítvány a közösségfejlesztés képzési szervezete, Kunbábonyban, a Kunszentmiklóshoz tartozó tanyabokorban vásárolta meg a volt tanyasi iskolát, majd felújítva megnyitotta a közösségek cselekedni és tanulni vágyó tagjai számára 1997-ben. A térségbe ismeretlenül érkezett, ám azzal a szándékkal, hogy a közösségfejlesztés hazai központjaként a térség hasznára fordítsa tudását.

\section{Fejlesztési folyamat:}

\section{feltárás, kapcsolatépítés, információ, képzés.}

\section{Partnerség.}

\section{A változásokhoz kedvezô légkör kialakítása.}

1. Feltárás - kapcsolatépítés 1997.

Célunk elsố körben a Kunszentmiklós statisztikai körzetbe tartozó 10 település megismerése volt, de hamarosan beláttuk, hogy Kunszentmiklós vonzáskörzetébe csak 4 kistelepülés tartozik, amely jobban átlátható számunkra is, mint a teljes kistérség.

Önkormányzatokkal és azok szövetségével, hivatalokkal, agrár - és vállalkozói támogató szakemberekkel és szervezetekkel, intézményekkel, iskolákkal, múvelôdési házzal, civil szervezetekkel (amelyból nagyon kevés volt), nyugdíjas klubokkal és fóként helyi polgárokkal vettük fel a kapcsolatot. 
A feltárás - kapcsolatépítés során megismerkedtünk jónéhány térségi programmal, elnyert pénzeszközök ellenére, azok sikertelenségeivel.

Mi magunk több pályázatot is írtunk a helyi munkára a kunszentmiklósi önkormányzat számára is, legtöbbször sikerrel - de hozzá kell tenni, hogy kicsiny mértékú támogatásokról volt szó.

Megismertük és megtapasztaltuk a térség problémáit. Közösséghiány, önszerveződés, állampolgári kezdeményezés hiánya.Az önkormányzatok egy részében a saját érdekek előbbre helyezése a köz érdekénél. Küszködés a nagyon alacsony aranykorona értékú, kis méretú földeken. Munkanélküliség, képzetlenség, tóke nélküliség, szegénység, cigány lakossággal szembeni előítélet. Nagyon rossz minőségú úthálózat, szemételhelyezési problémák, csatornázás, ivóvíz hiánya. Viszont minden településen telefon, jónéhányon vezetékes gáz. Tanyavilág.

Közvetlenül nem a helyi gazdaságfejlesztést célozta a fejlesztôi beavatkozás, de minden, a közösséget megmozdító tevékenységre szükség volt ahhoz, hogy magukra találjanak az emberek. Ezek járultak hozzá ahhoz, hogy egyre kedvezóbb légkör jöjjön létre a közösségi változások befogadásához.

Kunbábonyban, Kunpeszéren egyesület alakult, helyi újság, aktív közéleti szerepvállalás (önkormányzati választásokon), közösségi rendezvények sokasága, civil és vállalkozói képzések indultak el a fejlesztési folyamat elsô két évében. Láthatóan örömmel találtak egymásra az emberek a közös tevékenységekben, amelyek szükséges képességek teljes birtokában voltak a helyiek, de arra a kis "moccantás" -ra volt szükség, amelyet a közösségfejlesztők hoztak a településekre.

Egyre inkább megérett a kunbábonyi közösség arra, hogy a szórakoztató közösségi együttlétek mellett a település nehezebb sorsú tagjaival és a szorító megélhetési problémákkal is foglalkozzon. Ezzel ugyan nem mindenki értett egyet, hiszen ez a korábbi és azidei közösségi gyakorlattól távol állt és sokkal nagyobb felelôsséget jelentett, de volt néhány elkötelezett ember, akik a vállukra vették ezt a feladatot.

1998. áprilisban kezdődött el Kunbábonyban az a program, amely 30 helyi családot juttatott minôségi vetőmaghoz, növényvédôszerekhez, szaktanácsadáshoz. Az Autonómia Alapítvány támogatta ezt: $3 / 4$ rész vissza nem térítendô és $1 / 4$ rész a gazdálkodók által 6 hónapos részletben visszafizetendő összeggel. Egészében fél millió forintos programról volt szó. A konyhakertben a család szükségleteire megtermelhető zöldségféléket támogatta a program. Olyanok is vetőmaghoz jutottak, akik korábban nem múvelték meg a földet a tanya körül, gazdálkodási tapasztalattal nem rendelkeztek stb.

Időközben lezajlott egykétszer 1 hetes intenzív közösségi vállalkozásfejlesztési kurzus, amelyen 16 bábonyi vett részt, köztük 9 munkanélküli, a többiek potenciálisan azok. A képzést a Munkaügyi Központ és a Civil Kollégium támogatta. A résztvevôk önálló gazdaságuk tervét készítették el a tanfolyamon, de körvonalazódott a közös gazdasági tevékenység is.

A képzést követően nagyon sok beszélgetés történt személyesen és csoportok- 
ban. Igyekeztünk minden lehetőséget kihasználni, hogy közelebb hozzuk az embereket a szövetkezés gondolatához: pl.: a látogatóban nálunk járó külföldi partnereinket elvittük a helyi gazdákhoz, közös beszélgetéseket szervezetünk velük, a közösségfejlesztés-munkahelyteremtés szemináriumunkra meghívtuk a helyieket, ahol kapcsolatokra tehettek szert, múködő foglalkoztatási programokat ismerhettek meg.

Segítettük a munkanélkülieket az önfoglalkoztatási pályázat megírásában - ôstermelôvé válásban.

A helyiek úgy gondolták, hogy először ki kell próbálni, hogy egyedül megy-e, és ha nem, akkor szövetkeznek. Ehhez el kellett telni egy gazdasági évnek. Ezalatt látszottak meg az egyéni gazdálkodás problémái, a vetőmag, növényvédőszerek beszerzése, a föld megmunkálása, a növényvédelem és az értékesítés területén is.

Nekiláthattunk tehát ennyi előzmény után annak, hogy szövetkezés elókészítésére hívjuk össze a helyi gazdálkodókat. 1 évvel a képzés után két beszélgetés zajlott le. Az elsô még inkább csak latolgató, fontolgató szinten, de a második már a konkrét szervezési feladatokat vitatta meg. Ekkor állapodtunk meg abban, hogy három egymást követô este a következô kérdéseket tárgyaljuk végig: Milyen előnyökkel jár a szövetkezet az egyéni gazdálkodóknak, mi legyen a közös tevékenység, mi nem? Hogyan alakuljon a közös pénzügyi gazdálkodás? Mit tartalmazzon az alapszabály - melyek az eldöntendő kérdések? A beszélgetések résztvevői közül többen beiratkoztak a következô vállalkozásra felkészítô képzésre, behozva a lemaradásukat.

A Kunbábonyi Beszerzô, Termeltetô és Értékesítô Szövetkezet végül 1999. januárjábanalakult meg, amelybe földdel rendelkező és földet bérlő tagok is beléptek. Célul azt tûzték ki, hogy a tagok jövedelemhez ill. kiegészítéshez a pályakezdôk pedig a gazdálkodási tapasztalathoz jussanak. A bejegyzést egy helyi jogász segítette (ahogy a szövetkezet elnöke mondta: "egy hízott liba fejében"). Fúszerpaprika termesztését kezdte meg minden tag a saját v. bérelt földjén, ki-ki amennyit bírt a családtagjaival. Megszervezték a vetőmagbeszerzést, a vetőgépbérlést, a munkafolyamatokat, figyelték egymás területét, öntözését. Szerzôdést kötöttek a feldolgozó üzemmel és közösen értékesítették a paprikát, így jobb árat tudtak elérni (a nagyobb mennyiség miatt), mintha önállóan értékesítettek volna. Az értékesítési összegból az értékesített mennyiségnek megfelelően arányosan befizettek (2\%-ot) a szövetkezetbe a közös költségek fedezésére. Mindenki önkéntes munkában végezte a szervezési feladatot, saját gépkocsiját, telefonját használva.

Évente változóan 4-5 család termelt füszerpaprikát 5-7 ha-on kb. 350 q-t. 2001-ben szövetkezeten kívül gazdálkodóktól is felvásároltak paprikát a szerződött mennyiség teljesítése érdekében. Az együttes szerződéskötéssel magasabb árat értek el. A közös értékesítés fejébena külsók valamennyivel többet fizettek a szövetkezetnek, mint a tagok.

Közösen végezték el azokat a dolgokat, amely egyedül költségesebb, vagy eszköz híján nem ment volna.

2003-ig jól múködött ez a rendszer, de akkor a paprika ára ugyanannyi lett a kis 
mennyiség értékesítése esetén, mint nagyobb mennyiségben. Előbb fizetett a feldolgozó, ha egyénileg értékesített valaki, mintha közösen. Így a szövetkezet egyre inkább beszüntette a paprika értékesítő tevékenységét. Pályázatokat nem sikerült benyújtaniuk, hiszen az önerőnek igen szúkében voltak, csak a saját munkaerejüket tudták bevinni.

\section{A szövetkezet nehézségei:}

Csak azok tudtak a szövetkezetben eredményesen múködni, aki rendelkeztek minimális alaptôkével az induláshoz, akiknek a családtagjai is részt vettek a kézi erôvel végzendő munkákban, és akik megbíztak abban, hogy a szövetkezeten keresztül történô értékesítéskor is megkapják a termésük után járó pénzt.

Fizetett menedzsmentje a szövetkezetnek nem volt, amely így csak a legminimálisabb szervezést tudta biztosítani. A kívülrôl jövố lehetôségeket nem tudták kihasználni. Az időközben változó mezôgazdasági politika és törvények az újtípusú szövetkezetek helyett a családi gazdaságokat, majd a termelői csoportokat támogatták.

Ez a szövetkezet túl kicsi volt ahhoz, hogy lépést tudjon tartani az EU-s követelményekkel. Amikor megalakult, jövedelemkiegészítést nyújtott a benne résztvevôknek, de valódi jövedelmi tényezôvé nem vált a tagok életében. A fiatalok más életpályát választottak.

A képzés szükségességét felismerve a szövetkezet elnöke ezüst majd aranykalászos gazdaképzésben vett részt, ahol a többi gazdálkodóval meg tudták osztani információikat és tapasztalataikat.

\section{Továbbterjedés:}

A kunbábonyi fejlesztési folyamat hatására és hasonló módszertani lépésekkel még egy szövetkezet alakult a térségben sertéstenyésztésre. Ez a szövetkezetek csak akkor múködik, ha a tagok érdeke úgy kívánja, tehát ha az értékesítés elönyösebb a szövetkezeten keresztül, mint egyénileg. Ennek a szövetkezetnek agilis, egyénileg is erôsen érdekelt, fiatal vezetôje van, aki megfelelô információval, kapcsolatokkal rendelkezik. Tartják magukat ahhoz az elvhez, hogy azt csinálják együtt, ami egyedül nem megy és csakis önként vállalt módon.

A jó közösségi vállalkozáshoz-szövetkezethez elengedhetetlen, hogy a tagok mindegyike ismerje fel a közösségi gazdálkodás előnyét, ismerje fel saját érdekeit, és legyen olyan vezetôje, akit szakmailag, emberileg is elismer a közösség, aki képes a szervezésre, megújulásra és a változó körülményekkel való lépéstartásra.

\section{Térségi gazdaságfejlesztési folyamat}

Időközben 2000-ben térségi gazdaságfejlesztési tervezési folyamat indult, mint a 10 település, mindhárom szektorának részvételével. Átfogó gazdaságfejlesztési terv 
nem született. A résztvevők az információáramlás hiányában látták minden fejlesztés akadályát. Akkor ezt a hiányt településenként információs pontok felállításával kívánták enyhíteni, de a várakozásnak csak néhány helyen sikerült megfelelni, átütő eredményt nem ért el. Ezt követte egy újabb térségi közös tervezés, a foglalkoztatási megállapodás előkészítése 2005-2007 között, amelyhez összesen 31 szervezet csatlakozott: önkormányzatok, képzô intézmények, civil szervezetek, vállalkozások, szövetkezetek, takarékszövetkezet. A térség foglalkoztatási és képzési stratégiája elkészült. A prioritásokat felállították. Konkrét elemzés nem készült arról, hogy mi valósult meg ebből, de a 31 szervezet közös erőfeszítést nem tett annak érdekében, hogy a stratégiát cselekvésre váltsa. A szemléletformálásban elért eredményt a konkrét kormányzati intézkedések, az egyedi érdekek mindig felülírták. Hozadéka azért volt ennek a tervezó munkának, amelyet a következő esettanulmányban mutatok be:

\section{Reflex Szociális Szövetkezet}

2007-re elkészült a térség szélessávú internet és kábeltévé hálózata. Az információáramlásban a 2005-ben elindult Puszta Rádió (kisközösségi rádió) ugyan már pozitív változást indított el, de ez az egész térségre (a sugárzási korlát miatt) nem tudott kihatni. A foglalkoztatási paktumban kiemelt szerepet kapott a fiatalok megtartása és új közösségi szolgáltatások elindításának szükségessége. Így együttesen, kombinálva a szükségleteket a meglévő erőforrással azt eredményezte, hogy a térségi tévé megszervezésébe kezdtek a fejlesztook a felsőfokú tanulmányokat folytató, helyi fiatalokkal. Többszörös volt a cél: az információáramlás segítése a kábeltévén keresztül térségi tévé múködtetésével, a fiatalok megtartása, tudásuk használata a térség javára, számukra olyan gyakorlóterep kialakítása, amely életpályájuk tervezéséhez megfelelő alapot ad. A szövetkezeti forma nagyon kiváló arra, hogy közös tulajdonú vállalkozást vezetve olyan képességek birtokába jussanak, amelyet pályakezdóként nem tudnának elérni.

Kapóra jött az OFA pályázati kiírása szociális szövetkezet alapítására, amelyen sikerrel indultak a fiatalok és 2008-ban bejegyeztették a Reflex Szociális (közhasznú) Szövetkezetet Kunszentmiklóson.

A fiatalok egy része a hosszú elókészület miatt eltávolodott a kezdeményezéstôl, csatlakoztak viszont munkát keresôk, a tévézés iránt érdeklődők. Az alapító 7 tag között volt egyetemista, munkanélküli, hasznos tudással rendelkezô középkorú, amatôr videós rokkant nyugdíjas. A közösség nem igazán állt össze, az üzleti oldalt azonban egyre határozottabban kezdték felépíteni. Jelenleg 2 alkalmazottjuk van, 1 pályakezdő diplomás (szociológus) és egy középkorú rokkant nyugdíjas.

Megegyeztek a kábelhálózat tulajdonos önkormányzati térségi társulással a hálózat használatáról, lebonyolították a támogatott projektet, többször hitelt vettek fel, amit teljes mértékben visszafizettek és mindeközben kiépítették a térségben az önkéntes kis tévéstúdiók hálózatát. Ez utóbbit már saját forrásaikból. 
A tevékenység, a térségben élők számára egy olyan új szolgáltatást jelent, amelyet nem ók fizetnek, ugyanakkor általa információhoz jutnak és önmagukat is jobban megismerik. A tévé a települések rendezvényeit, a különböző szervezetek tevékenységét, önkormányzatok munkáját mutatja be. Ezt a formációt társadalmi vállalkozásnak ${ }^{2}$ nevezhetjük.

\section{Szociális gazdaság megjelenése a fejlesztési folyamatban}

Más területen is kísérletet tettünk arra, hogy közösségi vállalkozás létrehozását segítsük. Ennek alapjai támogatott foglalkoztatási, munkaerőpiacire-integrációs programok voltak 2002-2012 között. Két kistelepülésen Közösségi információs központ és kávéház, teleház, mûvelődési ház civil szervezet általi üzemeltetésében jelent meg, négy településen közösségi munka, idősek házi gondozása, térségi mosoda a szociális ellátás mellé és a városban családi napközi valósult meg. Úgy gondoltuk, hogy az új közösségi szolgáltatások, mivel a helyi szükségletekre épültek, hosszútávon fennmaradnak, mégha kevesebb ember foglalkoztatásával is, de akik benne dolgoznak a projektek időtartama alatt, azok kapnak annyi pluszt, amellyel az elsődleges munkaerőpiacon is megtalálják a helyüket. Az egyik közösségi központ 10 évig, a családi napközi pedig 8 évig tudta szolgálni a helyi közösségeket, majd az előbbi visszaalakult mûvelődési ház-könyvtárrá, az utóbbi pedig megszûnt bölcsőde megnyitása miatt.

2010 körül kezdtek el sokasodni a gondok. A közfeladatot ellátó civil szervezetek egyre kevésbé tudták fenntartani a szolgáltatásaikat. Az állami támogatások átalakultak. Egy-egy Unios projekt csak a támogatási időszak alatt tudott múködni. Át kellett gondolni, hogy a szervezeti fenntarthatóság érdekében milyen új stratégiát kell követni, illetve, hogy a korábbi foglalkoztatási projektekben, illetve közösségi szolgáltatásokban alkalmazott munkatársak számára milyen megoldásokat lehet találni. A munkaerôpiac beszúkülésével az nem volt várható, hogy máshol munkát találnak, különös tekintettel arra, hogy a munkatapasztalatuk, képzettségük a civil szolgáltatás ellátásában kiválónak bizonyult, azonban ilyen típusú munkakörök az elsôdleges munkaerôpiacon nincsenek.

(Egy kutatás tárgya lehet az, hogy a különbözô civil foglalkoztatási projektben szervezett képesség, ismeret, jártasság, munkatapasztalat mennyiben tud megfelelni az elsödleges munkaeröpiacon.)

Elébe kellett menni a várható problémának, felhasználva a szövetkezet szervezésben szerzett tapasztalatokat. Olyan tevékenységet kellett választani, amiben kellő biztonsággal mozognak a munkavállalók, illetve amelyre fizetóképes kereslet van.

\footnotetext{
${ }^{2}$ Társadalmi vállalkozás: olyan vállalkozás, amely kritikus társadalmi problémát hatékony, innovatív módon kezel pénzügyileg fenntartható módon. A pénzügyi eredmény visszatér a közösséghez, hogy elősegítse a társadalmi jó megvalósulását, a munkahelyteremtést és/vagy egyéb gazdasági és társadalmi elönyöket a marginalizálódott közösségek számára. (www.nesst.org felhasználásával)
} 


\section{Vissza Kunbábonyba}

\section{Összetett célok:}

A munkanélkülivé váló civil szervezeti alkalmazottak számára munkafeltételek teremtése. Olyan új szolgáltatások, tevékenységek vállalása, amelynek ellátásához megvan a kellố tudás, tapasztalat és a vevố részéról a fizetóképesség, azaz valódi gazdasági tevékenység legyen. Mindez történjen közösségi módon, mindazok összefogásával, aki felelősséget éreznek a környezetükben élő emberek sorsa iránt és mindazok részvételével, akik bármilyen szempontból érintettek.

Az elókészület során az érintett civil szervezetek vezetôi, tagjai, partnerei, munkavállalói több összejövetelen tárgyalták meg a lehetőségeket.

A korábbiakban bemutatott fejlesztési tevékenységek, a folyamatos tanulás és információgyújtés is hozzájárult ahhoz, hogy a szociális szövetkezet megalapításában láttak a résztvevốk jövőt.

Az Adacs-Bábony Szociális Szövetkezet 2011-ben 9 taggal alakult meg. Tagjai egymást jól ismerik, kipróbálták egymást nagyon sok közösségi aktivitásban. Az egymáshoz tartozás, a 'mi' tudat elóbb született meg, mint a szövetkezet. Egy jól múködô közösség vállalkozott arra, hogy közösen gazdasági tevékenységet folytassanak annak érdekében, hogy tagjaik számára munkalehetőséget, jövedelmet biztosítsanak és olyan tevékenységet folytassanak, amely nem csak a tagjaikra, hanem a környezetükre is pozitív hatást gyakorol.

2011. novemberétôl a szövetkezet látja el a Civil Kollégium épületének üzemeltetését,amelyért szolgáltatási díjban részesül. Ezzel az Alapítvány harmadára csökkentette az épületüzemeltetési költségét, így ez a váltás az Alapítványnak pénzügyileg is megéri. A haszon azonban nem ebben mérhető igazán. Olyan folyamatot sikerült ezzel a konstrukcióval elindítani, amely most még csak a kezdeti lépéseknél tart ugyan, de benne van a fenntarthatóság ígérete, mivel belülról fakad, nem külsố befolyásra indult és egy olyan közösség van mögötte, amely felelôsségtudattal rendelkezik, kész az újításra, együttmúködő és összetartó, képes új értékek létrehozására.

A szövetkezeti tagok különböző kvalitású emberek, így különböző módon járulnak hozzá a szövetkezet tevékenységéhez. Mindenki végez önkéntes munkát, amelyet belső elszámolási rendszerben rögzítenek (minden munkával töltött óra egyenértékú: a ráfordított idôt jegyzik fel). Akik rendelkeznek más erőforrásokkal is (mint saját munkaereje) azok anyagi javakkal is hozzájárulnak a tevékenységhez (gépek, nyersanyag), amit szintén órára számolnak át és jegyeznek fel.

A jövedelemmel nem rendelkező tagok alkalmi munkavállalóként is dolgoznak a szövetkezetnél, ők így vegyesen, idôt (az önkéntes munkáért), fizetést (az alkalmi munkáért) kapnak.

E munka mellett többféle kísérletet is elindítottak: lekvárt fốztek, szörpöt készítettek a környéken fellelhetô (termesztett és vadon termô) gyümölcsökből. Tésztát,kolbászt, szalámit készítettek, tortát, süteményt sütöttek. Mindazt amihez értenek és amihez az alapanyag helyben rendelkezésre állt. Mindezeket egyelőre kicsiben, az ide látogató vendégeknek, de ha tudják üzemszerúen gyártani a termé- 
keket, akkor majd el is adják ezeket.

2013-ban kezdték el a "Közösségi Öngyógyító Kert" tevékenységüket, amely egy 2000 m2-es kert a Civil Kollégium mögött. Itt növénytársítással termelnek zöldséget, füszer- és gyógynövényt. A kert maga egy olyan bemutató, foglalkoztató hely is lesz, ahol a képzésekre, nyári egyetemekre Kunbábonyba érkezók és családtagjaik megismerhetik a növénytársításos termesztést, a termések feldolgozását, tárolását, megkóstolhatják a gyógy-és fúszernövényekkel készült ételeket. Készítenek sörkollektoros aszalót is, amit ebben az évben kipróbálnak és igyekeznek a környéken elterjeszteni.

Közel egy év alatt sikerült annyi pénzt összegyưjteniük, hogy Kunbábonyban meg tudtak vásárolni egy telket, amelyen egy alápincézett épületalap van. Azt tervezik, hogy ezen építenek fel egy élelmiszer feldolgozót.

\section{Összefoglalva}

Ezek a kezdeményezések nem egymástól elszigeteltek, mégha idôben és némileg térben is egymástól távol helyezkednek el. A folyamatokat mozgató közösség ugyanaz. A térség, mint hely, a maga adottságaival, értékeivel és hiányával szintén ugyanaz.

A Warren által meghatározott közösség funkciókat ${ }^{3}$ mindhárom példa magában hordozza:

Szocializációs közeg a szövetkezet, egymáshoz csiszolja a tagokat, közösen kialakított normák és szabályok mentén múködnek, az egyéni célok nem nyomják el a közösségi célokat. A közösség tagjai segítik egymást, szolidárisak egymás iránt, kiegészítik egymás erôforrásait. A szövetkezet elősegíti a tagok gazdasági boldogulását, jövedelmet, munkát és olyan egyéb támogatást nyújt, amely lehetôvé teszi az egyéni gyarapodást is. A szövetkezet révén lehetôvé válik a tagok részvétele a "hatalom" gyakorlásban, a döntéshozatalban, a közösségi cselekvésben, ugyanakkor folyamatos reflektálást jelent a környezeti tényezőkre. A szövetkezet önmagában is társadalmi kontrollt képez.

A Kunbábonyi Szövetkezet és az Adacs-Bábony Szociális Szövetkezet esetében a nagyobb erôforrással rendelkezôk kiegyenlítő (szolidáris) magatartása a domináns a többiek felé. A Reflex Szociális Szövetkezet esetében a szervezeten túlmutató társadalmi szükséglet kielégítése a meghatározó.

Talán - most még pontosan nem tudható, de a súlyos gazdasági és társadalmi

\footnotetext{
3 - szocializáció, melyen keresztül a közösség bizonyos értékeket olt tagjaiba; - a gazdasági boldogulás funkciója - a közösség megélhetôségi lehetőséget biztosít tagjainak; - társadalmi részvétel, teljesítve a társasági élet iránti általános igényt; - társadalmi kontroll, megkövetelve a közösség értékeinek betartását; - kölcsönös támogatás, mely folyamat segítségével a közösség tagjai megvalósítják azokat a feladatokat, amelyek túl nagyok, vagy túl sürgósek ahhoz, hogy egy egyedülálló személy kezelni tudja.
} 
helyezet is befolyásolja, hogy az Adacs-Bábony Szociális Szövetkezet a közösségre teszi a legnagyobb hangsúlyt, amely kihozza mindenkiból a legtöbbet, megújul és folyamatosan fenntartja az egymás és környezete iránti figyelmet.

Mindhárom vállalkozás: folyamatos, tervezett, jövedelemtermelő gazdasági tevékenységet folytat/folytatott. Mindhárom társadalmi célt követ, amelyek közül mindháromra jellemzố a munkához, jövedelemhez juttatása azoknak, akik saját erejükból nem tudnak munkához jutni. (legyenek azok pályakezdô diplomások a gyakorlat hiánya miatt, vagy rokkant nyugdíjasként az elsődlegesnek nevezett munkaerőpiacon hátrányos megkülönböztetést elszenvedók). Mindhárom szolidáris, hiszen tagjai különböző társadalmi és gazdasági státuszúak, ugyanakkor egymás szükségleteire figyelők és azt kiegészítők.

Ezek a példák nem elegendőek ahhoz, hogy különbözô típusait alakítsuk ki a szolidáris, szociális vagy közösségi vállalkozásoknak. Ez talán nem is fontos, hiszen a tagoktól és szükségleteiktól függ, hogy mivé válik a szervezet.

A helyi gazdaságfejlesztés lehet nagyszabású, egységes elveken nyugvó, minden lakosra kiterjedő (pl: alternatív energiára való átállás) és lehet sok apró lépésból álló, azokat egymáshoz csiszoló folyamatos közösségi gazdasági tevékenység. Minden a helytól, az ott élő emberektől függ.

„Nem a fejlódés vagy a haladás a fontos, hanem a harmónia és az egyensúly fenntartása a minket körülvevó világban" (Tinker 1994)

\begin{tabular}{|c|c|c|c|}
\hline megnevezés & $\begin{array}{l}\text { Kunbábonyi } \\
\text { Szövetkezet }\end{array}$ & $\begin{array}{c}\text { Reflex Szociális } \\
\text { Szövetkezet }\end{array}$ & $\begin{array}{c}\text { Adacs-Bábony } \\
\text { Szociális } \\
\text { Szövetkezet }\end{array}$ \\
\hline kezdeményezó & helyi közösség & fejlesztó szervezet & helyi közösség \\
\hline $\begin{array}{c}\text { meghatározó } \\
\text { személy/személyek }\end{array}$ & $\begin{array}{l}\text { helyi születésú, } \\
\text { gazdálkodó, } \\
\text { felsőfokú } \\
\text { végzettségû }\end{array}$ & $\begin{array}{c}\text { felsófokú } \\
\text { tanulmányokat } \\
\text { folytató helyi } \\
\text { fiatalok } \\
\text { (3 fö) }\end{array}$ & $\begin{array}{l}\text { korábban egyesületben } \\
\text { tevékenykedôk (4 fô), } \\
\text { köztük szakmával } \\
\text { rendelkezố munkanél- } \\
\text { küliek, felsőfokú vég- } \\
\text { zettségú, közel } 10 \text { éve } \\
\text { beköltözők }\end{array}$ \\
\hline domináns jellege & szolidáris & társadalmi & közösségi \\
\hline alapítás & 1999. & 2008 & 2011. \\
\hline forma & szövetkezet & $\begin{array}{l}\text { nonprofit közhasznú } \\
\text { szociális szövetkezet }\end{array}$ & szociális szövetkezet \\
\hline tagok & ôstermelók & magánszemélyek & magánszemélyek \\
\hline tulajdon & $\begin{array}{l}\text { egyforma mértékú } \\
\text { minden tagnak }\end{array}$ & $\begin{array}{c}\text { egyforma mértékú } \\
\text { minden tagnak }\end{array}$ & $\begin{array}{l}\text { egyforma mértékú } \\
\text { minden tagnak }\end{array}$ \\
\hline $\begin{array}{c}\text { szavazati jog a } \\
\text { döntéshozatalban }\end{array}$ & 1 tag $=1$ szavazat & 1 tag $=1$ szavazat & 1 tag $=1$ szavazat \\
\hline vezetés & $\begin{array}{c}\text { tagokból választott } \\
3 \text { fôs vezetőség }\end{array}$ & $\begin{array}{c}\text { tagokból választott } \\
3 \text { fős vezetőség }\end{array}$ & $\begin{array}{c}\text { tagokból választott } \\
3 \text { fôs vezetőség }\end{array}$ \\
\hline alkalmazottak & nincs & $\begin{array}{l}\text { a tagok közül atipi- } \\
\text { kus foglalkoztatás }\end{array}$ & $\begin{array}{l}\text { a tagok közül atipi- } \\
\text { kus foglalkoztatás }\end{array}$ \\
\hline
\end{tabular}




\begin{tabular}{|c|c|c|c|}
\hline megnevezés & $\begin{array}{l}\text { Kunbábonyi } \\
\text { Szövetkezet }\end{array}$ & $\begin{array}{c}\text { Reflex Szociális } \\
\text { Szövetkezet }\end{array}$ & $\begin{array}{c}\text { Adacs-Bábony } \\
\text { Szociális } \\
\text { Szövetkezet }\end{array}$ \\
\hline $\begin{array}{l}\text { a tagok } \\
\text { társadalmi, } \\
\text { gazdasági } \\
\text { státusza }\end{array}$ & $\begin{array}{l}\text { földtulajdonnal } \\
\text { rendelkezô magán } \\
\text { gazdálkodók, } \\
\text { pályakezdók } \\
\text { földtulajdon } \\
\text { nélkül }\end{array}$ & $\begin{array}{l}\text { felsôfokú tanulmá- } \\
\text { nyokat folytatók, } \\
\text { pályakezdők diplo- } \\
\text { mások, munkanél- } \\
\text { küliek, legelább } \\
\text { középfokú } \\
\text { végzettségúek }\end{array}$ & $\begin{array}{l}\text { különbözô diplomával } \\
\text { rendelkezók, szak- } \\
\text { munkások, munkanél- } \\
\text { küliek, gazdálkodók, } \\
\text { máshol alkalma- } \\
\text { zottak, nyugdíjasok }\end{array}$ \\
\hline $\begin{array}{l}\text { vállalkozási } \\
\text { tevékenység }\end{array}$ & $\begin{array}{l}\text { mezôgazdasági } \\
\text { termék } \\
\text { termeltetése, } \\
\text { értékesítése }\end{array}$ & $\begin{array}{l}\text { közszolgáltatás, } \\
\text { térségi televízió } \\
\text { múködtetése }\end{array}$ & $\begin{array}{c}\text { civil szervezetnek } \\
\text { nyújtott épületüze- } \\
\text { meltetési szolgáltatás, } \\
\text { kertészeti tevékenység }\end{array}$ \\
\hline önkéntesség & $\begin{array}{l}\text { tevékenységben } \\
\text { és a vezetésben }\end{array}$ & $\begin{array}{l}\text { tevékenységben és a } \\
\text { vezetésben, nem } \\
\text { csak tagok részéról }\end{array}$ & $\begin{array}{l}\text { tevékenységben és a } \\
\text { vezetésben, nem } \\
\text { csak tagok réstéról }\end{array}$ \\
\hline $\begin{array}{l}\text { a tagok közötti } \\
\text { elszámolás }\end{array}$ & $\begin{array}{l}\text { a végzett munka a- } \\
\text { lapján (megtermelt } \\
\text { termék) }\end{array}$ & $\begin{array}{l}\text { alkalmazotti } \\
\text { fizetés }\end{array}$ & $\begin{array}{l}\text { belső elszámolási } \\
\text { rendszer a vég- } \\
\text { zett munka alapján }\end{array}$ \\
\hline $\begin{array}{c}\text { tagok } \\
\text { érdekeltsége }\end{array}$ & $\begin{array}{c}\text { jövedelemhez, vagy } \\
\text { jövedelem } \\
\text { kiegészítéshez } \\
\text { jutás }\end{array}$ & $\begin{array}{c}\text { munkatapasztalat } \\
\text { szerzés, } \\
\text { munkaviszonyból } \\
\text { eredó jövedelem, } \\
\text { önálló vállalkozás } \\
\text { múködtetése }\end{array}$ & $\begin{array}{l}\text { közösséghez való } \\
\text { tartozás, a } \\
\text { szolidaritásból való } \\
\text { „részesedés”, } \\
\text { jövedelemhez, } \\
\text { jövedelemkiegészí- } \\
\text { téshez jutás }\end{array}$ \\
\hline $\begin{array}{c}\text { korábbi } \\
\text { közösségi } \\
\text { tevékenység }\end{array}$ & $\begin{array}{c}\text { az idôsebb } \\
\text { tagok } \\
\text { között }\end{array}$ & nem volt & $\begin{array}{l}\text { minden tag részt vett } \\
\text { együtt közösségi } \\
\text { tevékenységekben }\end{array}$ \\
\hline $\begin{array}{l}\text { szövetkezeti } \\
\text { ismeretek }\end{array}$ & $\begin{array}{c}\text { a tsz időkból az } \\
\text { idősebb tagok } \\
\text { esetén }\end{array}$ & nem volt & $\begin{array}{l}\text { tanultak alapján, tsz } \\
\text { időkből idősebbeknél } \\
\text { korábbi Kunbábonyi } \\
\text { Szövetkezeti tagság }\end{array}$ \\
\hline $\begin{array}{c}\text { az eróforrással } \\
\text { rendelkezook nagyobb } \\
\text { arányú hozzájárulása } \\
\text { a közöshöz }\end{array}$ & jellemző & nem jellemző & jellemzô \\
\hline közös vagyon & nincs & $\begin{array}{l}\text { pályázat útján } \\
\text { elnyert támoga- } \\
\text { tásból, üzleti } \\
\text { tevékenységbool } \\
\text { fejlesztés }\end{array}$ & $\begin{array}{c}\text { üzleti } \\
\text { tevékenységból } \\
\text { fejlesztés }\end{array}$ \\
\hline kapcsolati tóke & $\begin{array}{l}\text { térségen belül, } \\
\text { elsôsorban a } \\
\text { mezôgazdasági } \\
\text { tevékenységhez } \\
\text { kötődően és } \\
\text { rokonság révén }\end{array}$ & $\begin{array}{c}\text { a fejlesztó } \\
\text { szervezet révén és } \\
\text { a tevékenység } \\
\text { során kialakult }\end{array}$ & $\begin{array}{c}\text { a korábbi közös } \\
\text { tevékenység során } \\
\text { kialakult és a } \\
\text { személyes } \\
\text { státuszok } \\
\text { hozadékaként }\end{array}$ \\
\hline szaktudások & $\begin{array}{l}\text { mezôgazdasági } \\
\text { jellegú (alaptól a } \\
\text { felsőfokúig) }\end{array}$ & $\begin{array}{c}\text { nem a } \\
\text { tevékenységhez } \\
\text { kötődő }\end{array}$ & $\begin{array}{c}\text { sokrétű, részben a } \\
\text { tevékenységhez } \\
\text { kötődő }\end{array}$ \\
\hline fejlődési irány & $\begin{array}{l}\text { nem lépett } \\
\text { tovább, } \\
\text { megszûnt }\end{array}$ & $\begin{array}{l}\text { vállalkozási tevé- } \\
\text { kenység kismértékú } \\
\text { bővülése a fő tevé- } \\
\text { kenységhez kötődő }\end{array}$ & $\begin{array}{c}\text { a tagok tudásához, } \\
\text { képességeihez } \\
\text { igazodó tervek }\end{array}$ \\
\hline
\end{tabular}




\section{Felhasznált és ajánlott irodalom}

- Falu Város Régió, Területfejlesztési és területrendezési szakmai folyóirat 2012 $/ 1-2$.

- Sabine U. O'Hara: A társadalmi sokféleség tisztelete. Megjelent: Valuing Socio-diversity, International Journal of Social Exonomics, Vol. 22. No. 5, 1995. 31-49. Bumberák Mária fordítása

- A szociális szövetkezetek múködési modelljének kidolgozása a foglalkoztatás elôsegítése érdekében. Foglalkoztatási és Szociális Hivatal megbízásából a tanulmányt készítette a Budapesti Vállalkozásfejlesztési Kutató Intézet Nonprofit Kft, Budapest 2010.

- Területfejlesztési füzetek 2. Helyi gazdaságfejlesztés. Ötletadó megoldások, jó gyakorlatok. NFM, NGM, Budapest, 2010.

Ajánlott honlapok: www.kozossegfejlesztes.hu; www.szoszov.hu; www.nesst.org; www.szocialisgazdasag.hu; http://www.nth.gov.hu (szakirodalom jegyzék) 